\title{
PENGARUH YOUTUBER GADGET REVIEW, WORD OF MOUTH, DAN PRODUCT FEATURES TERHADAP MINAT MEMBELI PRODUK SMARTPHONE MERK SAMSUNG DI INDONESIA
}

\author{
Robbani Afdhalul Ikhsan ${ }^{1}$, Rusminah HS${ }^{2}$, Muh. Mujahid \\ Dakwah $^{3}$ \\ 1Sarjana Manajemen Fakultas Ekonomi dan Bisnis, Universitas Mataram \\ E-mail: xxx.robbani@gmail.com \\ ${ }^{23}$ Fakultas Ekonomi dan Bisnis, Universitas Mataram
}

\begin{tabular}{|c|c|}
\hline ARTICLE INFO & ABSTRACT \\
\hline 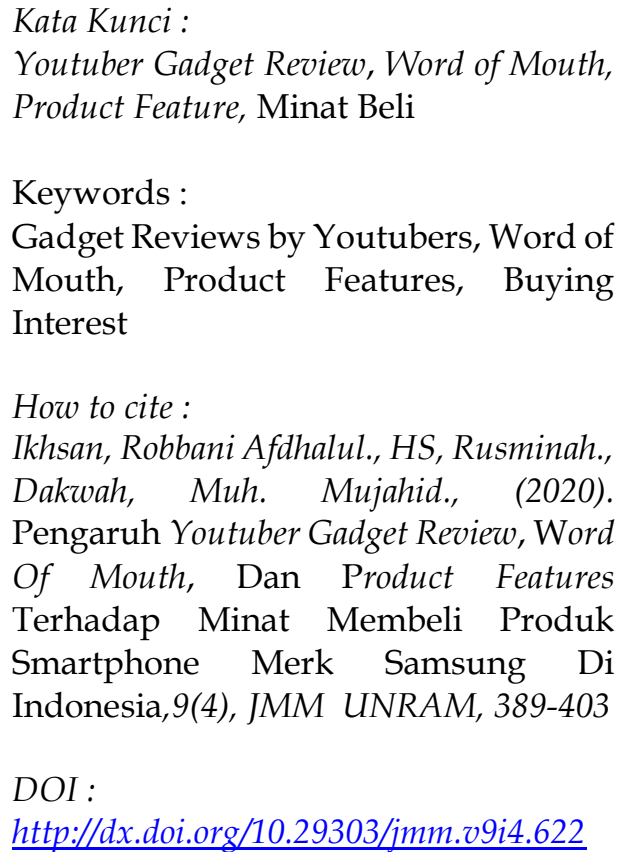 & $\begin{array}{l}\text { This study used an associative quantitative } \\
\text { method that measured the effect of independent } \\
\text { variables on the dependent variable. The purpose } \\
\text { of this research was to determine the significance } \\
\text { of the gadget reviews by YouTubers, word of } \\
\text { mouth, and product features on the buyers' } \\
\text { interest in Samsung smartphone product. The } \\
\text { method used in this study was non-probability } \\
\text { sampling method which used the purposive } \\
\text { sampling technique. The data were obtained } \\
\text { through a questionnaire in the form of google } \\
\text { form which was distributed to } 100 \text { people. The } \\
\text { result showed that; the gadget reviews by } \\
\text { YouTubers had no effect on the buyers' interest } \\
\text { where the significance level was 0,068, word of } \\
\text { mouth had an effect on the buyers' interest and it } \\
\text { was significant where the significance level was } \\
\text { 0,019, and product features also had a significant } \\
\text { effect on the buyers' interest where the } \\
\text { significance level was } 0,001 \text {. }\end{array}$ \\
\hline $\begin{array}{ll}\text { Dikumpulkan } & : 15 \text { Oktober } 2020 \\
\text { Direvisi } & : 16 \text { Desember } 2020 \\
\text { Dipublikasi } & : 18 \text { Desember } 2020\end{array}$ & $\begin{array}{l}\text { Tujuan penelitian ini adalah untuk mengetahui } \\
\text { signifikansi variabel Youtuber Gadget Review, } \\
\text { Word of Mouth dan Product Feature terhadap } \\
\text { Minat Membeli produk smartphone merk } \\
\text { Samsung. Metode yang digunakan pada } \\
\text { penelitian ini adalah metode non probapility } \\
\text { sampling dengan teknik purposive sampling, } \\
\text { data yang diperoleh melalui kuesioner berbentuk } \\
\text { google.form kepada } 100 \text { orang. Hasil penelitian } \\
\text { menunjukkan bahwa Youtuber Gadget Review } \\
\text { tidak memiliki pengaruh dengan tingkat }\end{array}$ \\
\hline
\end{tabular}




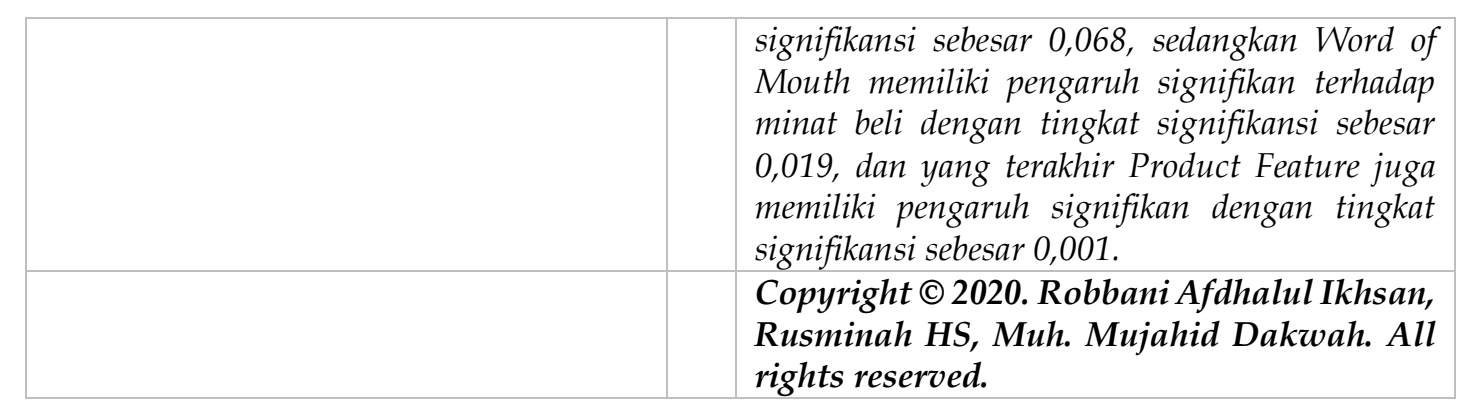

\section{PENDAHULUAN}

Menurut website kominfo pengguna aktif smartphone di Indonesia pada tahun 2019 sudah lebih dari seratus juta. Menjadikannya negara dengan populasi pengguna smartphone terbesar keempat di dunia (di belakang China, India, dan Amerika Serikat). Dengan begitu maka menjadikan Indonesia pangsa pasar yang sangat menjanjikan. Persaingan para produsen smartphone pun akan sangat ketat.

Samsung yang merupakan pemain lama di dunia per-smartphone-an tentunya memiliki kekuatan untuk bisa menggebrak pasar smartphone, khususnya di Indonesia. Salah satunya dengan meluncurkan produk-produk yang menjadi saingan merk lainnya. Samsung sendiri meluncurkan beberapa varian smartphone baru pada akhir tahun 2019 kemarin, yaitu Galaxy A series dan M series yang menyasar segmentasi pasar menengah.

Dari persaingan yang ada maka wajar jika produsen-produsen smartphone tersebut terus berusahan menjadi yang terbaik agar bisa menarik minat konsumen terhadap produknya. Menurut Schiffman dan Kanuk (2004:25), menjelaskan bahwa pengaruh eksternal, kesadaran akan kebutuhan, pengenalan produk dan evaluasi alternatif adalah hal yang dapat menimbulkan minat beli konsumen. Pengaruh eksternal ini terdiri dari faktor sosial budaya dan usaha pemasaran. Dari hal tersebut tentunya faktor eksternal yang menjadi jalan masuk perusahaan agar menarik minat beli konsumen. Seperti memasarkan produk-produknya melalui media online, membuat produk yang inovatif, ataupun membentuk citra merk yang baik sehingga masyarakat secara tidak langsung akan memiliki kecenderungan terhadap merk tertentu.

Melalui artikel Markplus berjudul "Flirting with Brands" edisi 1 Mei 2017 dijelaskan bahwa strategi pemasaran digital saat ini memanfaatkan konten YouTube yang dibuat anak muda sebagai bagian dari iklan produk. Strategi ini digunakan agar pesan iklan tetap sampai ke audiens tanpa merasa sedang menonton iklan. Audiens saat ini menginginkan pesan nyata dan natural yang disampaikan oleh para Youtuber. Karena para Youtuber memiliki penggemar mereka sendiri, pesan yang disampaikan menjadi terasa dekat dan bisa dipercaya. Konsep ini kemudian kita kenal sebagai endorser.

Selain komunikasi jalur digital tentunya komunikasi jalur 'tradisional' masih memiliki dampak terhadap minat beli seseorang terhadap produk smartphone. Word of Mouth Communication atau komunikasi mulut ke mulut tergantung pada penyebaran informasi yang dilakukan seseorang kepada orang lain. Menurut Brown et al (2005:125) word of mouth terjadi ketika konsumen berbicara kepada orang lain mengenai pendapatnya tentang suatu merek, produk, layanan atau perusahaan tertentu pada orang lain. Konsumen lebih memerhatikan informasi yang berasal dari orang-orang yang dipercaya, seperti teman, kerabat, maupun keluarga. Ucapan atau 
perkataan dari mulut ke mulut (word of mouth) dapat menjadi metode promosi yang efektif.

Berdasarkan uraian diatas penelitian tentang minat beli ini penting untuk melihat sejauh mana pengaruh usaha perusahaan dalam hal ini yaitu perusahaan Samsung dalam menarik minat beli konsumen di Indonesia melalui kegiatankegiatan promosi yang sudah dibahas sebelumnya.

\section{TINJAUAN TEORI DAN PENGEMBANGAN HIPOTESIS}

\subsection{Minat beli}

Minat beli adalah bagian dari perilaku konsumen yang menjelaskan mengenai tahap konsumen saat mencari informasi. Minat beli merupakan bagian dari perilaku konsumen karena termasuk dalam tahapan pengambilan keputusan pembelian (Kotler P., 2002). Minat bisa muncu berdasarkan pengalaman dalam memilih, memakai, menginginkan dan mengonsumesi produk.

Untuk mengetahui kecenderungan seseorang memiliki minat beli, terdapat pengukuran yang dijabarkan menjadi 5 indikator minat beli seseorang terhadap suatu produk (Ferdinand, 2006).

a. Minat eksploratif, yaitu perilaku pencarian informasi suatu produk untuk melengkapi informasi yang sudah dimiliki sebelumnya.

b. Minat preferensial, kecenderungan minat pada selera seseorang yang dilihat dari perilaku terhadap suatu produk.

c. Minat transaksional, kecenderungan seseorang untuk melakukan transaksi berupa pembelian actual atau di masa yang akan datang.

d. Minat referensial, kecenderungan memberikan referensi produk terhadap orang lain yang memiliki kebutuhan sama dengan tujuan penggunaan produk untuk memenuhi dan memuaskan kebutuhan

\subsection{Review Snartphone}

Review smartphone pesan yang disampaikan melalui bahasa lisan atau oral yang disampaikan melalui internet. Ada beberapa hal mengapa review smartphone tidak masuk kedalam golongan electornic Word of Mouth. Yang pertama yaitu eWoM berbentuk tulisan dan sengaja disebarkan melalui internet, sementara review smartphone di YouTube disampaikan melalui bahasa lisan atau oral (Cheung, 2010). Kedua adalah pernyataan yang dikatakan oleh Lee-Young (2009) bahwa eWoM biasanya berbentuk anonymous meskipun masih bisa memengaruhi konsumen dengan catatan kredibilitas dan kualitas pesan terpercaya, sementara review smartphone disampaikan oleh seseorang yang menyebutkan identitas mereka secara kredibel di YouTube. Dengan hal ini review smartphone termasuk dalam golongan pesan testimonial yang dilakukan oleh endorser.

\subsection{Pesan testimonial}

Tesmonial termasuk ke dalam iklan karena digunakan para produsen untuk membuat konsumen mereka semakin percaya. Testimonial biasanya melibatkan endorser yang nantinya akan melakukan kesaksian mengenai produk untuk membangun kepercayaan konsumen. Menurut O'Guinn, Thomas. Allen, Chris. Semenik, Richard. Close Scheinbaum, Angeline (2014: 204), Nilai tersmoni terletak pada pemaparan mengenai sebuah brand serta manfaat yang dirasakan oleh spokesperson (narasumber). 
Franz-Rudolf Esch dalam Spring Gabler, mendefinisikan testimonial sebagai penampilan tokoh terkenal di suatu media yang bertujuan mempromosikan suatu produk. Tokoh tersebut harus memiliki kredibilitas dalam penyampaian pesan sehingga dapat membangun citra positif terhadap suatu merk.

Seorang reviewer smartphone di YouTube dapat dikategorikan sebagai expert spokespeople karena memiliki pengetahuan lebih di bidang smartphone. Reviewer akan memakai smartphone dalam jangka waktu tertentu untuk mendapatkan kesaksian selama menggunakannya. Sehingga reviewer bisa mengungkapkan opini mengenai smartphone tersebut (Arifin Budi Prasetya, 2017

Agar efektif diterima oleh khalayak, pesan harus memiliki daya tarik agar tertanam di benak konsumen. Indikator daya tarik pesan iklan menurut Kotler dan Armstrong (2012) harus mempunyai tiga sifat sebagai berikut:

a. Meaningful (bermakna)

Pesan iklan harus menunjukkan manfaat produk sehingga menarik konsumen untuk menggunakan atau menginginkan produk. Pesan iklan harus dapat mengatakan sesuatu yang menarik dari produk tersebut.

b. Believeble (dapat percaya)

Pesan iklan harus dapat dipercaya oleh konsumen dan memberikan informasi yang benar. Konsumen akan mempercayai manfaat produk sesuai janji yang ditawarkan dalam pesan iklan.

c. Distinctive (daya tarik itu harus khas/berbeda)

Pesan iklan harus menyatakan sesuatu yang membuat produk yang diiklankan lebih baik dan berbeda dari produk-produk pesaing. Dengan demikian, pesan iklan harus mengatakan sesuatu yang ekslusif atau tidak terdapat pada semua merek lain dalam suatu kategori produk tersebut.

\subsection{Word of Mouth}

Word of mouth (WOM) atau komunikasi dari mulut ke mulut merupakan proses komunikasi yang berupa pemberian rekomendasi baik secara individu maupun kelompok terhadap suatu produk atau jasa yang bertujuan untuk memberikan informasi secara personal (Kotler dan Keller, 2012).

Word of mouth berasal dari suatu bentuk yang timbul secara alamiah dan tidak didesain oleh perusahaan juga pemasar. Jadi word of mouth tersebut timbul karena keunggulan produk atau jasa. Alasan penggunaan word of mouth begitu kuat karena hal-hal sebagai berikut (Silverman, 2001:26):

1. Kepercayaan yang bersifat mandiri. Pengambilan keputusan akan mendapatkan keseluruhan, kebenaran yang tidak diubah dari pihak ketiga yang mandiri.

2. Penyampaian pengalaman. Penyampaian pengalaman adalah alasan kedua mengapa word of mouth begitu kuat. Ketika seseorang ingin membeli produk, maka orang tersebut akan mencapai suatu titik dimana ia ingin mencoba produk tersebut. Secara idealnya, dia ingin mendapat risiko yang rendah, pengalaman nyata dalam menggunakan produk.

\subsection{Product Features}

Product Feature (fitur produk) merupakan suatu atribut produk yang ditawarkan kepada konsumen. Fitur produk pada umumnya merupakan berbagai macam fungsi yang diberikan oleh perusahaan dalam memenuhi kebutuhan para konsumennya, dengan adanya fitur ini diharapkan produk perusahaan dapat 
memenuhi kebutuhan konsumen dan memberikan rasa puas pada konsumen pada produk perusahaan.

Menurut Kotler \& Amstrong (2012 : 273) fitur adalah sarana kompetitif untuk mendeferensiasikan produk perusahaan dengan pesaing. Melalui fitur, perusahaan dapat menciptakan diferensiasi produknya dari produk pesaing.

Sebagai salah satu bagian dari atribut produk, fitur merupakan sebuah karya yang kreatif, subjektif, yang diciptakan oleh produsen untuk menyenangkan, dan memberikan imformasi dan gambaran kepada konsumen tentang produk atau aspek produk.

\subsection{Hubungan Antar Variabel}

2.6.1. Hubungan antara Youtuber Gadget Review dengan Minat Beli

Menurut Mukhopadhyay, S. \& Chung, T.S (2015) bahwa review berpengaruh terhadap minat pembelian konsumen. Dimana dengan adanya review konsumen bisa mendapatkan informasi tentang suatu produk. Kredibilitas, kualitas serta kakuatan argumen dari informasi yang terdapat dalam review yang diberikan oleh konsumen memberikan efek pada persepsi penilaian seseorang terhadap suatu produk. Sehingga dapat memunculkan minat bagi konsumen. Berdasarkan penelitian terdahulu tentang pengaruh youtuber review dengan minat beli yang dilakukan menunjukan bahwa ada pengaruh dari Youtuber Review terhadap minat beli. Seperti penelitian yang dilakukan Ahmad Farki (2016) yang meneliti tentang pengaruh Youtuber review dan rating terhadap kepercayaan dan minat pembelian pada Online Marketplace di Indonesia. Dalam penelitian ini dimana review dan rating yang menjadi variabel independent dan minat beli dan kepercayaan menjadi variabel dependent. Dan hasil dari penelitian ini membuktikan bahwa review mempengaruhi tingkat minat beli konsumen dalam berbelanja pada online marketplace. Dimana semakin bagus review yang diberikan oleh costumer maka semakin tinggi minat untuk berbelanja di online marketplace, begitupun sebaliknya.

H1 : Youtuber Gadget Review berpengaruh signifikan terhadap minat membeli smartphone merk Samsung di Indonesia.

\subsubsection{Hubungan antara Word of Mouth dengan Minat Beli}

Menurut Kotler dan Keller (2012) word of mouth merupakan proses komunikasi yang berupa pemberian rekomendasi baik secara individu maupun kelompok terhadap suatu produk atau jasa yang bertujuan untuk memberikan informasi secara personal.. Dimana orang-orang sekitar dapat mempengaruhi seseorang untuk menetapkan produk pilihannya, diantaranya dengan cara merekomendasikan secara langsung. Hasil penelitian Nava Prasetya, Ariadi Santoso, dan Siti Wahyuni (2019) yang meneliti tentang pengaruh corporate image dan word of mouth terhadap minat beli produk pada madani skincare kediri menunjukkan bahwa variabel word of mouth berpengaruh secara positif dan signifikan terhadap variabel minat beli produk. Dalam penelitian ini variabel word of mouth juga memiliki pengaruh dominan terhadap variabel minat beli dibandingkan variabel corporate image. Responden lebih percaya informasi yang mereka dengar dari orang terdekat daripada memperoleh informasi dari iklan, poster, maupun baliho dari pihak eksternal. Hal ini menunjukkan bahwa jika konsumen mendapatkan informasi yang positif tentang produk tersebut dari orang lain, selanjutnya akan menimbulkan minat beli konsumen yang menerima informasi tersebut. 
$\mathrm{H} 2$ : word of mouth berpengaruh signifikan terhadap minat membeli smartphone merk Samsung di Indonesia

\subsubsection{Hubungan antara Product Feature dengan Minat Beli}

Menurut Dewi dan Jatra (2013) fitur produk (Product Feature) merupakan karakteristik tambahan yang dirancang untuk menambah ketertarikan konsumen terhadap produk atau menyempurnakan fungsi produk. Fitur-fitur menarik yang dimiliki suatu produk tentunya dapat menarik minat seseorang utuk mencobanya. Apalagi dalam kasus ini adalah smartphone yang dimana salah satu yang paling dilihat adalah fitur-fiturnya. Semakin canggih dan modern fitur yang dimiliki suatu smartphone maka semakin tinggi pula orang-orang ingin memiliki smartphone tersebut sehingga dapat meningkatkan minat orang-orang untuk membeli smartphone tersebut. Pada penelitian Akhmad Faisal (2014) mengatakan bahwa fitur produk berpengaruh positif terhadap minat beli. Karena fitur produk pada smartphone merupakan salah satu alasan mereka untuk membeli di waktu yang akan datang, namun perusahaan harus terus mempertahankan dan mengembangkan fitur-fitur terbaru kedepannya.

H3 : Product Feature berpengaruh signifikan terhadap minat membeli smartphone merk Samsung di Indonesia.

\section{METODE PENELITIAN}

Jenis penelitian yang digunakan dalam penelitian ini adalah kuantitatif asosiatif. Dalam hal ini penelitian kuantitatif asosiatif yang bertujuan untuk mengukur dampak dari variabel bebas (Youtuber Gadget Review, Word of mouth, dan Product Feature) terhadap variabel terikat (Minat Beli) dengan menggunakan data yang berupa angka sebagai alat analisis.

Lokasi dari penelitian ini adalah seluruh wilayah Indonesia dengan populasi seluruh konsumen yang ada di Indonesia. Sampel yang digunakan berjumlah 100 responden dengan kriteria yaitu responden yang pernah menonton review smartphone merk Samsung yang ada di YouTube serta mengetahui tentang fitur-fitur yang ada pada produk smartphone merk Samsung.

Penelitian ini menggunakan metode pengambilan sampel non-probability sampling dan teknik yang digunakan yaitu purposive sampling. Alat untuk mengumpulkan data menggunakan kuesioner google form yang disebar langsung melalui social media. Skala pengukuran yang digunakan yaitu skala likert, dengan bobot nilai 1 = Sangat Tidak Setuju; 2 = Tidak Setuju; $3=$ Netral; $4=$ Setuju; $5=$ Sangat Setuju. Untuk interval kelas dan kategori jawaban responden dapat dilihat dibawah ini

Tabel interval kelas dan kategori jawaban responden

\begin{tabular}{|c|c|c|c|c|c|}
\hline \multirow{2}{*}{ No. } & \multirow{2}{*}{ Nilai } & $\begin{array}{c}\text { Youtuber Gadget } \\
\text { Review }\left(\mathrm{X}_{1}\right)\end{array}$ & $\begin{array}{c}\text { Word Of } \\
\text { Mouth }\left(\mathrm{X}_{2}\right)\end{array}$ & $\begin{array}{c}\text { Product Features } \\
\left(\mathrm{X}_{3}\right)\end{array}$ & $\begin{array}{c}\text { Minat Beli } \\
(\mathrm{Y})\end{array}$ \\
\hline 1 & $1,00-1,80$ & $\begin{array}{c}\text { Sangat Kurang } \\
\text { Baik }\end{array}$ & $\begin{array}{c}\text { Sangat } \\
\text { Kurang Baik }\end{array}$ & $\begin{array}{c}\text { Sangat Tidak } \\
\text { Menarik }\end{array}$ & $\begin{array}{c}\text { Sangat } \\
\text { Rendah }\end{array}$ \\
\hline 2 & $1,81-2,60$ & Kurang Baik & Kurang Baik & Tidak Menarik & Rendah \\
\hline 3 & $2,61-3,40$ & Netral & Netral & Netral & Netral \\
\hline 4 & $3,41-4,20$ & Baik & Baik & Menarik & Tinggi \\
\hline 5 & $4,21-5,00$ & Sangat Baik & Sangat Baik & Sangat Menarik & $\begin{array}{c}\text { Sangat } \\
\text { Tinggi }\end{array}$ \\
\hline
\end{tabular}


Prosedur analisis data yang digunakan yang pertama yaitu uji intrumen, diantaranya uji validitas digunakan untuk mengukur sah atau valid tidaknya suatu kuesioner, dan uji reliabilitas digunakan untuk mengukur suatu kuesioner yang merupakan indikator dari variabel atau konstruk. Selanjutnya uji asumsi klasik diantaranya uji normalitas yang digunakan untuk mengetahui ada tidaknya normalitas dalam model regresi, yaitu dengan melihat normal probability plot yang membandingkan distribusi komulatif dari distribusi normal, selanjutnya uji multikolinieritas digunakan untuk menguji apakah model regresi ditemukan adanya korelasi antar variabel independen, dan uji analisis regresi linier berganda digunakan untuk membuktikan ada tidaknya hubungan fungsional atau hubungan kausal antara dua atau lebih variabel bebas. Dan yang terakhir yaitu uji hipotesis diantaranya uji $\mathrm{F}$ digunakan untuk melihat apakah model yang dianalisis memiliki tingkat kelayakan model yang tinggi yaitu variabel-variabel yang digunakan mampu untuk menjelaskan fenomena yang dianalisis, selanjutnya uji $t$ digunakan untuk untuk mengetahui apakah pengaruh variabel independen berpengaruh secara parsial terhadap variabel dependen bersifat menentukan (signifikan) atau tidak, dan uji $\mathrm{R}^{2}$ digunakan untuk mengukur seberapa jauh kemampuan model dalam menerangkan variasi variabel dependen.

\section{PEMBAHASAN}

\subsection{Deskripsi Karakteristik Responden}

Dari 100 data yang diperoleh melalui penyebaran kuesioner melalui media sosial seperti Twitter, Whatsapp, Instagram, dan Facebook dengan teknik purposive sampling, didapat informasi bahwa 57\% responden adalah laki-laki dan $43 \%$ responden adalah perempuan. Kategori usia didominasi oleh responden yang berumur 18-30 tahun yaitu sebesar $87 \%$. Tingkat pendidikan responden didominasi oleh S1-S3 (55\%). Pekerjaan responden didominasi oleh pelajar dan mahasiswa (62\%). Mayoritas pendapatan responden yaitu dibawah $\mathrm{Rp} 1.000 .000,00$ per bulan (45\%). Dan mayoritas responden berasal dari Bali dan Nusa Tenggara (43\%).

\subsection{Deskripsi data indikator variabel}

\subsubsection{Variabel Youtuber Gadget Review}

Menurut Arifin Budi Prasetya (2017) Youtuber Gadget Review merupakan pesan testimonial yang dilakukan oleh reviewer smartphone di YouTube yang memiliki pengetahuan lebih di bidang smartphone. Reviewer akan memakai smartphone dalam jangka waktu tertentu untuk mendapatkan kesaksian selama menggunakannya. Sehingga reviewer bisa mengungkapkan opini mengenai smartphone tersebut. Dalam review smartphone harus mampu menarik perhatian, menggunakan bahasa yang mudah dimengerti, menyampaikan pesan secara actual dan objektif sehingga membangkitkan kebutuhan responden, serta memberikan alternatif untuk mencapai kebutuhan. Hasil tanggapan dari orang yang mengisi kuesioner secara keseluruhan variable Youtuber Gadget Review memiliki penilaian yang masuk kedalam kategori baik dimana rata-rata jawaban responden menghasilkan nilai rata-rata 4,15. Artinya responden merasa bahwa pesan yang disampaikan oleh reviewer dapat diterima dengan baik. 


\subsubsection{Variabel Word of Mouth}

Menurut Kotler dan Keller (2012) Word of mouth merupakan proses komunikasi yang berupa pemberian rekomendasi baik secara individu maupun kelompok terhadap suatu produk atau jasa yang bertujuan untuk memberikan informasi secara personal. Dalam proses komunikasi word of mouth ini mencangkup informasi terkait produk yang dibicarakan, rekomendasi terhadap produk, serta dorongan dari orang lain untuk memiliki produk tersebut. Hasil dari tanggapan responden secara keseluruhan untuk variabel Word Of Mouth memperoleh nilai 3,66 dengan kategori baik. Artinya informasi, rekomendasi, dan dorongan yang diterima oleh responden dari orang lain diterima dengan baik dan dapat dipercaya.

\subsubsection{Variabel Product features}

Product feature merupakan karakteristik tambahan yang dirancang oleh perusahaan untuk menambah ketertarikan konsumen (Dewi dan Jatra, 2013), kerakteristik tersebut mencangkup kebutuhan akan fitur, kelengkapan, ketertarikan, serta kemudahan dalam penggunaan fitur-fitur yang ada. Hasil tanggapan dari orang yang mengisi kuesioner secara keseluruhan pada variabel Product feature mendapatkan rata-rata nilai 3,96 dimana masuk kedalam kategori menarik. Artinya responden menganggap bahwa fitur-fitur yang terdapat pada smartphone merk Samsung menarik baik itu dari kelengkapan fitur, kebutuhan responden akan fiturfitur yang ada, serta kemudahan dalam penggunaan.

\subsubsection{Variabel Minat Beli}

Menurut Assael (2001) minat beli merupakan kecenderungan konsumen untuk mengambil tindakan sebuah pembelian. Minat muncul karena stimulus dari luar dirinya, baik pemasaran maupun lingkungan. Stimulus dari luar menghasilkan motivasi untuk memutuskan membeli atau tidak membeli sama sekali. Indikator dalam variabel minat beli diantaranya minat eksploratif, minat preferensial, minat transaksional, minat referensial. Hasil dari rata-rata jawaban responden masuk kedalam kategori tinggi, dengan nilai rata-rata keseluruhan 3,91. Artinya minat beli responden terhadap produk smartphone merk Samsung berdasarkan penelitian ini tinggi, baik itu minat untuk mencari lebih banyak informasi, minat preferensial, minat referensial, maupun minat untuk membeli produk diwaktu yang akan datang.

\subsection{Hasil Analisis Data}

\subsubsection{Uji Instrumen}

a. Uji Validitas

Hasil analisis data dari uji instrumen yang pertama yaitu uji validitas. Suatu kuesioner dikatakan valid jika pertanyan pada kuesioner mampu untuk mengungkapkan sesuatu yang akan diukur oleh kuesioner tersebut dan jika $r$ hitung > r tabel dengan tingkat signifikansi 5\% (Ghozali, 2016).

\section{Hasil Uji Validitas}

\begin{tabular}{|c|c|c|c|c|}
\hline Variabel & $\begin{array}{c}\text { Butir } \\
\text { Pernyataan }\end{array}$ & $\begin{array}{c}\text { Pearson } \\
\text { corelation } \\
\text { (r hitung) }\end{array}$ & $\begin{array}{c}\mathrm{r} \\
\text { Tabel }\end{array}$ & Keterangan \\
\hline \multirow{3}{*}{$\begin{array}{c}\text { Youtuber } \\
\text { Gadget Review }\end{array}$} & $\mathrm{X} 1.1$ & 0,714 & 0,197 & Valid \\
\cline { 2 - 5 } & $\mathrm{X} 1.2$ & 0,651 & 0,197 & Valid \\
\cline { 2 - 5 } & $\mathrm{X} 1.3$ & 0,727 & 0,197 & Valid \\
\cline { 2 - 5 } & $\mathrm{X} 1.4$ & 0,694 & 0,197 & Valid \\
\hline
\end{tabular}




\begin{tabular}{|c|c|c|c|c|}
\hline & $\mathrm{X} 1.5$ & 0,606 & 0,197 & Valid \\
\hline \multirow{4}{*}{$\begin{array}{c}\text { Word Of } \\
\text { Mouth }\end{array}$} & $\mathrm{X} 2.1$ & 0,761 & 0,197 & Valid \\
\cline { 2 - 5 } & $\mathrm{X} 2.2$ & 0.734 & 0,197 & Valid \\
\cline { 2 - 5 } & $\mathrm{X} 2.3$ & 0,798 & 0,197 & Valid \\
\cline { 2 - 5 } & $\mathrm{X} 2.4$ & 0,684 & 0,197 & Valid \\
\hline \multirow{4}{*}{$\begin{array}{c}\text { Product } \\
\text { Feature }\end{array}$} & $\mathrm{X} 3.1$ & 0,720 & 0,197 & Valid \\
\cline { 2 - 5 } & $\mathrm{X} 3.2$ & 0,791 & 0,197 & Valid \\
\cline { 2 - 5 } & $\mathrm{X} 3.3$ & 0,825 & 0,197 & Valid \\
\cline { 2 - 5 } & $\mathrm{X} 3.4$ & 0,853 & 0,197 & Valid \\
\cline { 2 - 5 } & $\mathrm{X} 3.5$ & 0,472 & 0,197 & Valid \\
\hline \multirow{4}{*}{ Minat Beli } & $\mathrm{Y} 1.1$ & 0,775 & 0,197 & Valid \\
\cline { 2 - 5 } & $\mathrm{Y} 1.2$ & 0,762 & 0,197 & Valid \\
\cline { 2 - 5 } & $\mathrm{Y} 1.3$ & 0,791 & 0,197 & Valid \\
\cline { 2 - 5 } & $\mathrm{Y} 1.4$ & 0,677 & 0,197 & Valid \\
\hline
\end{tabular}

Dari hasil uji validitas diatas menunjjukan bahwa nilai $\mathrm{r}$ hitung per item pernyataan memiliki nilai lebih besar dari $\mathrm{r}$ tabel yaitu 0,197 maka semua butir pertanyaan valid atau benar dalam mengukur gejala yang diukur dalam hal ini Kepercayaan Youtuber Gadget Review, Word Of Mouth, Product Feature dan Minat Beli.

b. Uji Reliabilitas

Selanjutnya uji reliabilitas yang digunakan untuk menguji reliabilitas kuesioner dengan menggunakan uji statistik Cronbach Alpha. Suatu konstruk atau variabel dikatakan reliabel jika memiliki Cronbach Alpha > 0,70 (Ghozali 2016).

Hasil Uji Reliabilitas

\begin{tabular}{|l|c|c|c|}
\hline \multicolumn{1}{|c|}{ Variabel } & $\begin{array}{c}\text { Cornbach } \\
\text { Alpha }\end{array}$ & Kriteria & Keterangan \\
\hline $\begin{array}{l}\text { Youtuber } \\
\text { Gadget } \\
\text { Review }\end{array}$ & 0,703 & 0,70 & Reliable \\
\hline $\begin{array}{l}\text { Word of } \\
\text { Mouth }\end{array}$ & 0,725 & 0,70 & Reliable \\
\hline $\begin{array}{l}\text { Product } \\
\text { Feature }\end{array}$ & 0,794 & 0,70 & Reliable \\
\hline Minat Beli & 0,743 & 0,70 & Reliable \\
\hline
\end{tabular}

Dari hasil uji reliabilitas diatas menunjukkan bahwa nilai koefisien Alpha Cronbach pada setiap variabel yang diteliti memiliki nilai lebih besar dari 0,70, sehingga dapat dikatakan bahwa kuesioner yang disebar reliabel.

\subsubsection{Uji Asumsi Klasik}

a. Uji Normalitas

Uji asumsi klasik yang pertama yaitu uji normalitas, untuk mengetahui ada tidaknya normalitas dalam model regresi, yaitu dengan melihat normal probability plot yang membandingkan distribusi komulatif dari distribusi normal. Distribusi normal akan membentuk satu garis lurus diagonal, dan ploting data residual akan dibandingkan dengan garis diagonal. Jika distribusi data residual normal, maka garis yang menggambarkan data sesungguhnya akan mengikuti garis diagonalnya (Ghozali, 2016). 


\section{Hasil Uji Normalitas}

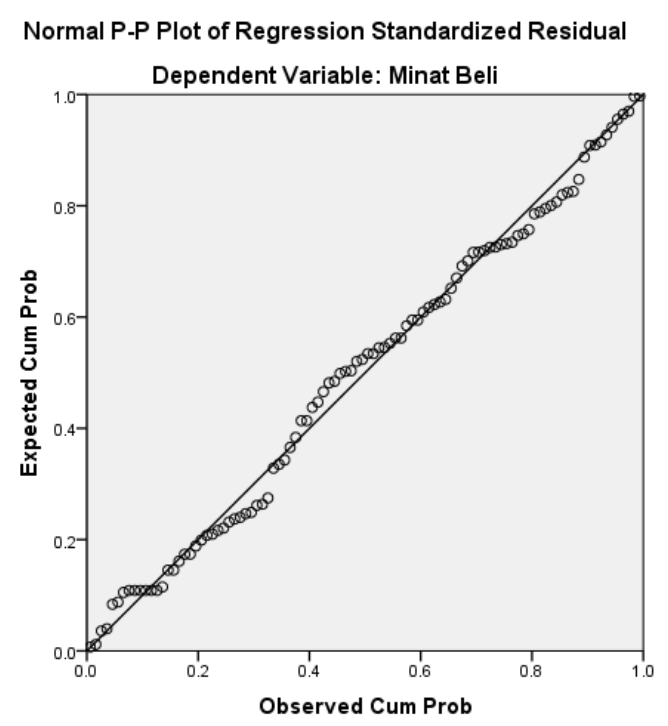

Dari hasil uji normalitas diatas dapat dilihat bahwa dalam kurva normal pplot terlihat titik menyebar di sekitar garis diagonal dan penyebarannya tidak terlalu jauh atau melebar, berarti menunjukan bahwa model regresi sesuai asumsi normalitas dan layak untuk menganalis pengaruh variabel-variabel bebas.

b. Uji Multikolinieritas

Untuk uji multikolinieritas, model yang baik seharusnya tidak terjadi korelasi di antara variabel independen dan tidak orthogonal atau nilai korelasi antar sesama variabel independen sama dengan nol. Dapat juga dilihat dari nilai tolerance dan Variance Inflation Factor (VIF), nilai toleransi yang besarnya di atas 0.1 dan nilai VIF di bawah 10 menunjukkan bahwa tidak ada multikolinieritas pada variabel independennya (Ghozali, 2016).

Berdasarkan hasil uji Multikolinier nilai VIF untuk setiap varibel memiliki nilai lebih kecil dari 10 serta nilai toleransi lebih besar dari 0,1 sehingga dapat dikatakan bahwa model regresi tersebut tidak terdapat multikolinieritas antara variabel dependen dengan variabel indipenden yang diteliti.

Hasil Uji Multikolinieritas dan Uji Analisis Linier Berganda

\begin{tabular}{|c|c|c|c|c|c|c|c|}
\hline \multirow{2}{*}{ Model } & \multicolumn{2}{|c|}{$\begin{array}{l}\text { Unstandardized } \\
\text { Coefficients }\end{array}$} & \multirow{2}{*}{$\begin{array}{c}\begin{array}{c}\text { Standardized } \\
\text { Coefficients }\end{array} \\
\text { Beta }\end{array}$} & \multirow[t]{2}{*}{$t$} & \multirow{2}{*}{ Sig. } & \multicolumn{2}{|c|}{$\begin{array}{l}\text { Collinearity } \\
\text { Statistics }\end{array}$} \\
\hline & B & Std. Error & & & & Tolerance & VIF \\
\hline 1 (Constant) & .991 & 2.757 & & .359 & .720 & & \\
\hline $\begin{array}{l}\text { Youtuber } \\
\text { Gadget } \\
\text { Review }\end{array}$ & .213 & .116 & .160 & 1.846 & .068 & .971 & 1.030 \\
\hline $\begin{array}{l}\text { Word of } \\
\text { Mouth }\end{array}$ & .243 & .102 & .229 & 2.381 & .019 & .796 & 1.257 \\
\hline $\begin{array}{l}\text { Product } \\
\text { Feature }\end{array}$ & .337 & .094 & .347 & 3.582 & .001 & .781 & 1.280 \\
\hline
\end{tabular}

Dari hasil tabel diatas juga dapat diperoleh persamaan regresi yaitu $\mathrm{Y}=$ $0,991+0,213 X_{1}+0,243 X_{2}+0,337 X_{3}+$ e. Diperolah nilai konstantanya bernilai positif yaitu 0,991, hal ini menujukkan bahwa apabila variabel Kepercayaan Youtuber Gadget 
Review, Word of mouth dan Product Feature sebesar 0,991 maka nilai Minat Beli juga sebesar 0,991. Pengaruh variabel Youtuber Gadget Review terhadap minat beli berdasarakan persamaan di atas diperoleh nilai koefisien regresi sebesar 0,213, ini artinya untuk setiap peningkatan variabel nilai sebesar 1 satuan maka akan meningkatkan minat beli sebesar 0,213. Sedangkan pengaruh variabel Word of mouth terhadap minat beli berdasarakan persamaan di atas diperoleh nilai koefisien regresi sebesar 0,243 , ini artinya untuk setiap peningkatan variabel nilai sebesar 1 satuan maka akan meningkatkan minat beli sebesar 0,243. Dan untuk pengaruh variabel Product Feature terhadap minat beli berdasarakan persamaan di atas diperoleh nilai koefisien regresi sebesar 0,337, ini artinya untuk setiap peningkatan variabel nilai sebesar 1 satuan maka akan meningkatkan minat beli sebesar 0,337

\subsubsection{Uji Hipotesis}

a. Uji F

Menurut Ferdinand (2014), uji F atau uji kelayakan model yang dilakukan untuk melihat apakah model yang dianalisis memiliki tingkat kelayakan model yang tinggi yaitu variabel-variabel yang digunakan mampu untuk menjelaskan fenomena yang dianalisis.

- Jika f hitung > f tabel, maka H0 ditolak. Hal ini berarti bahwa persamaan regresi dapat digunakan untuk memprediksi pengaruh Youtuber Gadget Review, Word of Mouth dan Product Feature terhadap Minat Beli produk smartphone merk Samsung di Indonesia.

- Jika f hitung < f tabel, maka H0 diterima. Hal ini berarti bahwa persamaan regresi tidak dapat digunakan untuk memprediksi pengaruh Youtuber Gadget Review, Word of Mouth dan Product Feature terhadap Minat Beli produk smartphone merk Samsung di Indonesia.

\begin{tabular}{|ll|r|r|r|r|r|}
\hline \multicolumn{2}{|c|}{ Hasil Uji F } \\
\hline Model & \multicolumn{1}{|c|}{$\begin{array}{c}\text { Sum of } \\
\text { Squares }\end{array}$} & Df & Mean Square & F & Sig. \\
\hline 1 & Regression & 254.367 & 3 & 84.789 & 13.461 & $.000^{\mathrm{b}}$ \\
& Residual & 604.673 & 96 & 6.299 & & \\
& Total & 859.040 & 99 & & & \\
\hline
\end{tabular}

Hasil dari uji $\mathrm{F}$ diatas menghasilkan nilai $\mathrm{F}$ hitung sebesar 13,461 dimana $\mathrm{F}$ tabelnya yaitu 2,70, sehingga $\mathrm{F}$ hitung lebih besar dari $\mathrm{F}$ tabel. Selain itu diperoleh juga nilai probabilitas signifikan sebesar 0,000 dimana lebih kecil dari 0,05. Artinya H0 ditolak dan Ha diterima. Dari hasil tersebut dapat disimpulkan bahwa variabel independen yang diteliti berpengaruh dan signifikan secara simultan terhadap variabel dependen yang diteliti.

\section{b. Ujit}

Selain itu untuk uji t dimana uji ini dilakukan untuk melihat apakah variabel independen berpengaruh secara parsial terhadap variabel dependen.berdasarkan kriteria uji $t$ jika $t$ hitung lebih besar dari t tabel maka hipotesis diterima, sebaliknya jika thitung lebih kecil dari $t$ tabel maka hipotesis ditolak. Dimana nilai $t$ tabel dalam penelitian ini adalah 1,984 . 


\begin{tabular}{|c|c|c|c|c|c|}
\hline \multirow[b]{3}{*}{ Model } & \multicolumn{2}{|c|}{ Hasil Uji t } & & & \\
\hline & \multicolumn{2}{|c|}{$\begin{array}{c}\text { Unstandardized } \\
\text { Coefficients }\end{array}$} & \multirow{2}{*}{$\begin{array}{c}\begin{array}{c}\text { Standardized } \\
\text { Coefficients }\end{array} \\
\text { Beta }\end{array}$} & \multirow[b]{2}{*}{$\mathrm{t}$} & \multirow[b]{2}{*}{ Sig. } \\
\hline & B & $\begin{array}{l}\text { Std. } \\
\text { Error }\end{array}$ & & & \\
\hline $1 \quad$ (Constant) & .991 & 2.757 & & .359 & .720 \\
\hline $\begin{array}{l}\text { Youtuber Gadget } \\
\text { Review }\end{array}$ & .213 & .116 & .160 & 1.846 & .068 \\
\hline Word of Mouth & .243 & .102 & .229 & 2.381 & .019 \\
\hline Product Feature & .337 & .094 & .347 & 3.582 & .001 \\
\hline
\end{tabular}

Berdasarkan kriteria Uji t jika Sig < 0,05 maka Ho ditolak dan Ha diterima berarti ada pengaruh signifikan variabel independent secara individual terhadap variabel dependen. Dan jika Sig > 0,05 maka Ha ditolak dan Ho diterima berarti tidak ada pengaruh signifikan variabel independent secara individual terhadap variabel dependen.

a. Variable Youtuber Gadget Review

Youtuber Gadget Review memiliki tingkat signifikansi sebesar 0,068. Dari hasil uji t pada variabel Youtuber Gadget Review menyatakan bahwa signifikansi uji $\mathrm{t}$ lebih besar dari 0,05 sedangakan nilai $\mathrm{t}$ hitung yang diperoleh sebesar 1,846 lebih kecil dari nilai ttabel 1,984. Dari hasil uji t pada variable Youtuber Gadget Review menyatakan bahwa variabel Youtuber Gadget Review tersebut berpengaruh negatif dan tidak signifikan terhadap Minat Membeli produk smartphone merk Samsung di Indonesia. Dengan demikian H0 diterima dan H1 ditolak. Pernyataan tersebut bermakna "Youtuber Gadget Review tidak berpengaruh terhadap Minat Membeli produk smartphone merk Samsung di Indonesia".

b. Variable Word of Mouth

Word of Mouth memiliki tingkat signifikansi sebesar 0,019. Dari hasil uji t pada variabel Word of Mouth menyatakan bahwa signifikansi uji $t$ lebih kecil dari 0,05 , sedangakan nilai thitung yang diperoleh sebesar 2,381 lebih besar dari nilai ttabel 1,984. Dari hasil uji t pada variabel Word of Mouth dinyatakan bahwa variabel tersebut berpengaruh positif dan signifikan terhadap Minat Membeli produk smartphone merk Samsung di Indonesia. Dengan demikian H0 ditolak dan H1 diterima. Pernyataan tersebut bermakna "Word of Mouth berpengaruh signifikan terhadap Minat Membeli produk smartphone merk Samsung di Indonesia".

c. Variable Product Feature

Product Feature memiliki tingkat signifikansi sebesar 0,001. Dari hasil uji $\mathbf{t}$ pada variabel Product Feature menyatakan bahwa signifikansi uji t lebih kecil dari 0,05, sedangakan nilai thitung yang diperoleh sebesar 3,582 lebih besar dari nilai ttabel 1,984. Dari hasil uji t pada variabel Product Feature dinyatakan bahwa variabel tersebut berpengaruh positif dan signifikan terhadap Minat Membeli produk smartphone merk Samsung di Indonesia. Dengan demikian H0 ditolak dan Ha diterima. Pernyataan tersebut bermakna "Product Feature berpengaruh signifikan terhadap Minat Membeli produk smartphone merk Samsung di Indonesia".

c. Uji R2 (Koefisien Determinasi)

Uji $R^{2}$ bertujuan untuk mengukur seberapa jauh kemampuan variabel independen dalam menjelaskan variasi variabel dependen. Nilai koefisien determinasi adalah antara nol dan satu. Nilai yang mendekati satu berarti adalah 
variabel independen memberikan hampir semua informasi yang dibutuhkan untuk memprediksi variabel dependen (Ghozali, 2016).

Hasil Uji $\mathbf{R}^{2}$

\begin{tabular}{|l|c|r|r|r|}
\hline Model & R & R Square & $\begin{array}{c}\text { Adjusted R } \\
\text { Square }\end{array}$ & $\begin{array}{c}\text { Std. Error of } \\
\text { the Estimate }\end{array}$ \\
\hline 1 & $.544^{\mathrm{a}}$ & .296 & .274 & 2.510 \\
\hline
\end{tabular}

Dari hasil tersebut dapat dilihat bahwa nilai R2 yaitu sebesar 0,296 atau sebesar 29,6\% yang merupakan nilai koefisien determinasi serentak dari variabel independen terhadap minat beli. Nilai tersebut menunjukan bahwa pengaruh variabel Youtuber Gadget Review, Word of Mouth dan Product Feature terhadap Minat Beli adalah 29,6\%. Sedangkan sisanya $(100 \%-29,6 \%=70,4 \%)$ dijelaskan oleh variabel lain di luar variabel penelitian yang tidak di masukkan ke dalam model penelitian ini.

\section{KESIMPULAN DAN SARAN}

\subsection{Kesimpulan}

1) Variabel Youtuber Gadget Review $\left(X_{1}\right)$ memiliki respon yang positif tetapi tidak berpengaruh dan signifikan terhadap Minat Membeli produk smartphone merk Samsung di Indonesia. Dibuktikan dengan nilai t hitung lebih kecil dari t tabel dan tingkat signifikanya lebih besar dari 0.05, yang artinya tidak signifikan. Maka dapat disimpulkan bahwa variabel Youtuber Gadget Review tidak berpengaruh pada Minat Membeli produk smartphone merk Samsung di Indonesia.

2) Variabel Word of mouth $\left(X_{2}\right)$ memiliki respon yang positif serta berpengaruh dan signifikan terhadap Minat Membeli produk smartphone merk Samsung di Indonesia. Dibuktikan dengan nilai $t$ hitung lebih besar dari $t$ tabel dan tingkat signifikanya lebih kecil dari 0.05, maka dapat disimpulkan bahwa variabel Word of mouth berpengaruh signifikan pada Minat Membeli produk smartphone merk Samsung di Indonesia.

3) Variabel Product Feature $\left(X_{3}\right)$ memiliki respon yang positif serta berpengaruh dan signifikan terhadap Minat Membeli produk smartphone merk Samsung di Indonesia. Dibuktikan dengan nilai $t$ hitung lebih besar dari $t$ tabel dan tingkat signifikanya lebih kecil dari 0.05, maka dapat disimpulkan bahwa variabel Product Feature berpengaruh signifikan pada Minat Membeli produk smartphone merk Samsung di Indonesia

\subsection{Saran}

1) Dari hasil penelitian terdapat variabel yang tidak memiliki pengaruh terhadap minat beli konsumen yaitu Youtuber Gadget Review, dimana Youtuber Gadget Review merupakan bagian dari pesan testimonial yang dilakukan pada platform Youtube. Itu membuktikan bahwa kegiatan pemasaran pada bidang tersebut belum maksimal. Perusahaan dapat melakukan beberapa cara, seperti memonitoring feedback dari orang-orang yang menonton video review gadget di Youtube. Seperti yang sudah dijelaskan sebelumnya Youtube merupakan platform yang sangat interaktif, dimana penonton dapat memberikan komentar maupun rating terhadap video yang mereka tonton. Oleh karena itu perusahaan dapat memanfaatkan hal tersebut guna memaksimalkan pemasaran melalui platform Youtube agar lebih menarik serta dapat meningkatkan minat penonton. 
2) Untuk variabel lainnya diharapkan perusahaan bisa menjadikan penelitian ini sebagai referensi untuk melakukan evaluasi kedapannya baik itu dengan meningkatkan strategi promosi di bidang word of mouth dengan menciptakan produk yang berkualitas serta menghadirkan layanan yang dapat memuaskan pelanggan, karena proses word of mouth yang positif terjadi akibat dari pelanggan yang merasa puas terhadap produk yang mereka gunakan. Kemudian untuk variabel Product Features perusahaan dapat menghadirkan fitur-fitur yang inovatif serta sesuai dengan apa yang dibutuhkan orang-orang saat ini, proses ini bisa juga dengan memanfaatkan dan mengevaluasi feedback yang didapatkan di platform Youtube tadi, untuk mengetahui apa yang dibutuhkan orang-orang.

\section{DAFTAR PUSTAKA}

Assael, H. (2001). Consumers Behavior and Market-ing Action. Edisi 3. Boston Massachusset: Kent Publishing Company.

Augusty, Ferdinand. (2006). Metode Penelitian Manajemen. Semarang: Badan Penerbit Universitas Diponegoro.

Brown, et al., (2005). Spreading The Words: Investigating Antecedents of Customer's Positive Word of Mouth Intention And Behavior in Retailing Context. Academy of Marketing Science Journals, Vol.33.

Cheung, C. M., \& Thadani, D. R. (2010). The Effectiveness of Electronic Word-of-Mouth Communication: A Literature Analysis. Bled eConference, 23, 329-345.

Farki, A. 2016. Pengaruh online customer review dan rating terhadap kepercayaan dan minat pembelian pada online marketplace di Indonesia (Doctoral dissertation, Institut Teknology Sepuluh Nopember).

Ghozali, Imam. (2016). Aplikasi Analisis Multivariete Dengan Program IBM SPSS 23 (Edisi 8). Cetakan ke VIII. Semarang : Badan Penerbit Universitas Diponegoro.

Kotler, Phillip and Keller, Kevin L. (2012). "Marketing Management" (Bob Sabran. Terjemahan). Jakarta: Erlangga.

Kotler, Philip, dan Gary Armstrong. 2012. Prinsip-prinsip Pemasaran. Edisi 13. Jilid 1. Erlangga : Jakarta.

Markeeters. "Vloggers: Flirting With Brands". Edisi Mei 2017

Mukhopadhyay, S., \& Chung, T. S. (2016). Preference instability, consumption and online rating behavior. International Journal of Research in Marketing, 33(3), 624-638.

O'guinn, T., Allen, C., Semenik, R. J., \& Scheinbaum, A. C. 2014. Advertising and integrated brand promotion. Nelson Education.

Prasetya, A. B. 2017. Pengaruh Pesan Testimonial Review Smartphone Terhadap Minat Beli Smartphone Pada Mahasiswa Di Yogyakarta. Skripsi. Yogyakarta: Universitas Gadjah Mada

Prasetya, N., Santoso, A., \& Wahyuni, S. 2019. Pengaruh Corporate Image Dan Word Of Mouth Terhadap Minat Beli Produk Pada Madani Skincare Kediri. Jimek: Jurnal Ilmiah Mahasiswa Ekonomi, 2(2), 249-264.

Schiffman, L.G. dan Kanuk, L.L. (2004). Perilaku Konsumen. Edisi 7. Jakarta. Prentice Hall International.

Tsang, A. S., \& Prendergast, G. (2009). Is a "star" worth a thousand words? The interplay between product-review texts and rating valences. European Journal of Marketing, $43,1269-1280$. 
Tsao, W. C. (2014). Which type of online review is more persuasive? The influence of consumer reviews and critic ratings on moviegoers. Electronic Commerce Research, 14(4), 559-583.

https:/ / www.cnnindonesia.com/teknologi/20190508204215-185-393203/3-fitursmartphone-yang-diincar-pengguna-indonesia (diakses pada 8 Oktober 2019, 20:15 WITA)

https://selular.id/2019/11/top-5-vendor-smartphone-di-indonesia-q3-2019/ (diakses pada 8 Oktober 2019, 22:37 WITA)

https://tekno.tempo.co/read/1181645/survei-kepemilikan-smartphone-indonesiaperingkat-ke-24 (diakses pada 8 Oktober 2019, 20:43 WITA) 